\title{
THE IMPACT OF GERMAN MACROECONOMIC NEWS ON EMERGING EUROPEAN FOREX MARKETS
}

\section{Michala Moravcová*}

\begin{abstract}
This paper analyses the impact of German macroeconomic news announcements and ECB meeting days on the conditional volatility of the Czech, Polish, and Hungarian Foreign Exchange markets as proxied by CZK/EUR, PLN/EUR, and HUF/EUR exchange rate returns over six years (2010-2015). A currency intervention period (11/2013-2015) in the Czech Republic is examined separately. EGARCH-type models with normal and Student's $t$-distributions are employed. The comprehensive analysis shows the following results. (i) The IFO index, Factory Orders increase and the PMI index from the Service Sector, the labour market data decrease conditional volatility of PLN/EUR. (ii) The IFO index and Industrial Production increase conditional volatility of HUF/EUR on the day of the announcement. (iii) Data from the labour market has a calming effect on CZK/ EUR after the central bank launched currency interventions. (iv) IFO index increases and the PMI index from the Manufacturing Sector decreases conditional volatility of CZK/EUR before currency interventions were introduced (2010-11/2013).
\end{abstract}

Keywords: exchange rate volatility, heteroscedasticity, EGARCH, macroeconomic news announcements

JEL Classification: C52, F31, F36, G15, P59

\section{Introduction and Motivation}

The purpose of this study is to examine the impact of German macroeconomic news announcements on the Czech, Hungarian, and Polish foreign exchange markets. Exchange rates are an important part of international trade and quite responsive to developments in the real economy. The Czech Republic, Hungary, and Poland are extremely open economies. Exports and imports are at very high levels relative to GDP. Exports of goods and services in the Czech Republic made up $83.0 \%$ of GDP, in Hungary $90.7 \%$ of GDP, and in Poland $49.6 \%$ of GDP in 2015. Not only the exports, but also the imports represented significant part of GDP. Particularly, imports of goods and services spoke for $76.8 \%$ of GDP in the Czech Republic, $81.8 \%$ of GDP in Hungary and $46.5 \%$ of GDP in Poland. All in all, net exports produced $3.47 \%$ of GDP in the Czech Republic, $5.32 \%$ of GDP in Hungary and $1.01 \%$ in Poland. ${ }^{1}$

* Michala Moravcová, Institute of Economic Studies, Charles University, Prague, Czech Republic (moravcovamichala@gmail.com)

I am thankful for useful comments from Roman Horváth, Evžen Kočenda, and two anonymous referees. The research was supported by the GAČR grant No. 16-09190. The usual disclaimer applies.

1 Data come from OECD database (https://data.oecd.org/trade/trade-in-goods-and-services.htm). 
Moreover, they say that EU member states contribute to the turnover of the foreign exchangetrade of the Visegrad Four (V4) countries by about $70 \%$. Germany is Central Europe's most important economic partner, and economic and trading relationship has brought mutual benefits. According to Paplowski (2016) the value of Germany investments in the V4 countries has doubled, from $€ 36$ billion to $€ 77$ billion in the period 2004-2012.

Exchange rate movements are also an important determinant of inflation and thus achieving the inflation target. This was demonstrated by the Czech National Bank's (CNB) decision to launch currency interventions on 7 November 2013. The bank set a minimum CZK/EUR value at a level of 27 to achieve an inflation target of $2 \%$, as measured by the annual increase in the consumer price index (CPI).

This paper tries to address the following questions:

(i) Do German macroeconomic news announcements influence the conditional exchange rate volatility of new EU countries? If so, does the news increase or decrease the volatility?

(ii) Do new EU market currencies show asymmetric effects in exchange rate returns, i.e. are downward price movements associated with higher volatility, whereas upward movements are associated with lower volatility?

(iii) Longmore and Robinson (2005), Yoon and Lee (2008) find evidence of volatility clustering and persistence, which indicates that large and small log-returns tend to occur in clusters in financial time series. Can this pattern be recognized in new EU currency exchange rates?

(iv) Do the Czech National Bank's interventions change the CZK/EUR exchange rate characteristics?

(v) Do the European Central Bank's meetings affect the volatility of the exchange rates of new EU members?

The Generalized autoregressive conditional heteroscedastic (GARCH) model developed independently by Bollerslev (1986) and Taylor (1986) is applied to estimate exchange rate volatility. The main contribution of this paper is to fill a gap in the literature by bringing very recent evidence of German macroeconomic news announcements on the conditional volatility of CZK/EUR, PLN/EUR, and HUF/EUR. Exchange rates are examined from 1 January 2010 to 31 December 2015, which corresponds to the period after the financial crisis. This period has not been examined yet. The impact of news announcements is measured as the deviation of the actual news value from the expected value. Moreover, the paper develops novel insights into the impact of foreign macroeconomic news releases on Czech currency market during the period of currency interventions. From a broader perspective, this paper also focuses on the impact of the European Central Bank's meeting days on the three examined exchange-rate volatilities similar to Jansen and de Haan (2005).

The remainder of this paper is organized as follows. Section 2 describes the related literature. Section 3 specifies the examined time series and macroeconomic news announcements. Section 4 presents the methodology. Section 5 reveals the results, which is followed by concluding remarks. 


\section{Review of the Related Literature}

The significance of the effect of macroeconomic news releases on financial markets has been intensively analysed previously in the literature. One strand of the literature focuses on the impact of macroeconomic data announcements on the stock market. For example, Jones et al. (2005), Erenburg et al. (2006), and Rigobon and Sack (2008). The other strand examines how macroeconomic news announcements influence foreign exchange markets. Andersen et al. (2003) find that surprise announcements (that is, divergences between expectations and the realization of news) produce conditional mean jumps and that highfrequency exchange rate dynamics are thus linked to fundamentals. Evans and Lyons (2008) also produce empirical evidence of the effects of macroeconomic news announcements on exchange rates. Fratzscher (2006) shows that macroeconomic news releases accounted for approximately $15 \%$ of the variations in exchange rates.

However, most of the recent research focuses on developed markets. New EU financial markets are under-researched. The impact of macroeconomic news announcements on these markets is examined in two areas. The first analyses the impact of domestic news and the second focuses on the impact of foreign news announcements on the new EU markets. Regarding the first one, Fišer and Horváth (2010) find that Czech macroeconomic data announcements have a calming effect on CZK/EUR conditional volatility. Büttner and Hayo (2012) show no evidence that Czech macroeconomic news affect the value of the CZK/EUR exchange rate. Égert and Kočenda (2014) show that during the pre-crisis period PPI index and unemployment rate affect the value of the CZK/EUR exchange rate, whereas during the crisis period, only GDP announcements have an impact on the mean CZK/EUR rate.

Concerning impact of foreign news on new EU markets, Hayo et al. (2010) show a deepening euro area influence on new EU countries over time and a corresponding reduction in the relative importance of U.S. shocks. Similarly, Büttner et al. (2012) suggest the growing importance of EU news after the Copenhagen Deal for European Union Enlargement in comparison to US news. Moreover, Hanousek et al. (2009) show that there are substantial positive spillover effects from the German stock market to the Czech stock market.

\section{Data}

Section 3 starts with exchange rates, then macroeconomic news and central bank announcements are quantified. The description of the model follows in Section 4.

\subsection{Foreign exchange rates}

The daily exchange rates of CZK/EUR, PLN/EUR, HUF/EUR are taken from MetaQuotes Software corresponding to the CET time zone for the period beginning on 1 January 2010 and ending on 31 December 2015. Under direct quoting, the spot exchange rate $S_{i}\left(x_{i} / l_{j}\right)$ is expressed as the amount $x$ of a currency $i$ (quoting currency) that one needs in order to buy one unit of currency $j$ (base or reference currency). In this case the Czech koruna, Polish zloty, and Hungarian forint are the quoting currencies and the euro is the base currency. 
Figure 1 | Plots of Daily Spot Rates (left) and Daily Percentage Returns (right) for the Case of CZK/EUR (first row), HUF/EUR (second row), and PLN/EUR (third row) exchange rates (the sample runs from 1 January 2010 to 31 December 2015).

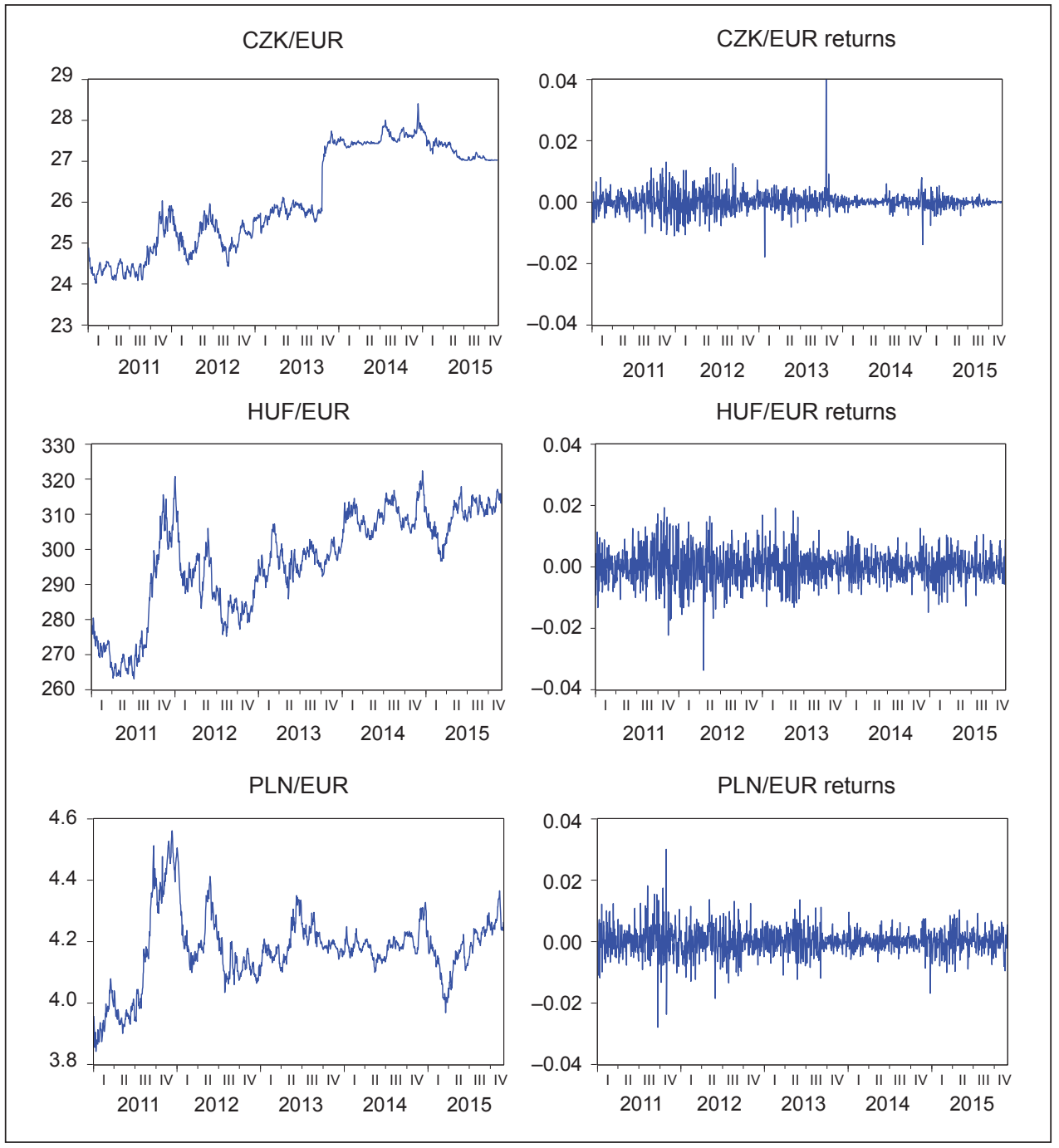

Source: Author - based on data from Metaquotes company

Daily data are transformed into percentage returns:

$$
r_{t}=\ln \left(\frac{R_{t+1}}{R_{t}}\right) * 100,
$$

where $r_{t}$ is the daily percentage return to the exchange rate and $R_{t}$ and $R_{t+1}$ denote the exchange rates on the current day $t$ and following day $t+1$, respectively. Daily exchange rates returns are stationary. 
Thus, a negative change in an exchange rate means that the amount of the quoting currency $i$ needed to buy one unit of currency $j$ becomes smaller, which means an appreciation of the quoting currency $i$ with respect to the reference currency $j$. Similarly, a positive change represents a depreciation of the quoting currency.

The dynamics of the exchange rates under research are presented in Figure 1. The Czech koruna and Hungarian forint weakened relative to the euro during the examined time period. However, part of the Czech koruna weakness was caused by the Czech National Bank (CNB) currency interventions. The CNB commenced foreign exchange interventions on 7 November 2013 and planned to use it until mid-2017. The CNB prevents the koruna from excessive appreciation below CZK 27/EUR by intervening on the foreign exchange market. On the weaker side of the CZK 27/EUR level, the CNB is allowing the koruna exchange rate to float. The big spike in CZK/EUR daily returns in Figure 2B shows the start of exchange rate interventions. Regarding Polish zloty it has been resilient to the euro and has kept its value, oscillating around 4.2.

Table 1 | Descriptive Statistics of the Examined New-EU Exchange Rates: CZK/EUR, PLN/EUR, HUF/EUR

\begin{tabular}{|l|c|r|r|r|r|r|r|}
\hline & CZK/EUR & $\begin{array}{c}\text { CZK/EUR } \\
\text { returns }\end{array}$ & $\begin{array}{c}\text { CZK/EUR } \\
\text { returns }\end{array}$ & HUF/EUR & \multicolumn{1}{|c|}{$\begin{array}{c}\text { HUF/EUR } \\
\text { returns }\end{array}$} & PLN/EUR & $\begin{array}{c}\text { PLN/EUR } \\
\text { returns }\end{array}$ \\
\hline \multicolumn{7}{|c|}{ no intervention day } \\
\hline Mean & 25.969 & 0.000 & 0.000 & 293.309 & 0.000 & 4.139 & 0.000 \\
\hline Median & 25.715 & 0.000 & 0.000 & 296.000 & 0.000 & 4.157 & 0.000 \\
\hline Max. & 28.255 & 0.046 & 0.015 & 322.680 & 0.027 & 4.566 & 0.035 \\
\hline Min. & 23.946 & -0.022 & -0.022 & 261.200 & -0.022 & 3.828 & -0.032 \\
\hline Std. Dev. & 1.175 & 0.004 & 0.003 & 15.536 & 0.005 & 0.132 & 0.005 \\
\hline Skewness & 0.117 & 1.364 & -0.040 & -0.336 & 0.448 & 0.073 & 0.301 \\
\hline Kurtosis & 1.581 & 23.294 & 5.815 & 1.892 & 5.443 & 3.215 & 8.177 \\
\hline Jarque-Bera & 138.130 & $28,004.760$ & 529.800 & 128.680 & 518.210 & 5.280 & $2,122.240$ \\
\hline Probab. & 0.000 & 0.000 & 0.000 & 0.000 & 0.000 & 0.070 & 0.000 \\
\hline $\begin{array}{l}\text { ARCH } \\
\text { LM test } \\
\text { (heterosc.) }\end{array}$ & - & 0.064 & 0.000 & - & 0.000 & - & 0.000 \\
\hline Obser. & 1,603 & 1,603 & 1,603 & 1,603 & 1,603 & 1,603 & 1,603 \\
\hline
\end{tabular}

Note: Values in the column named "CZK/EUR returns no intervention day" do not include data from 7 November 2013 (the day of intervention announcement). The daily return on that day was $4.717 \%$. Dropping off this one day from data sample results in different values in 2 nd and 3 rd column.

Source: Author - based on data from Metaquotes company 
Figure 2 | Level of Conditional Volatility

\section{A: PLN/EUR Returns - Level of Conditional Volatility}

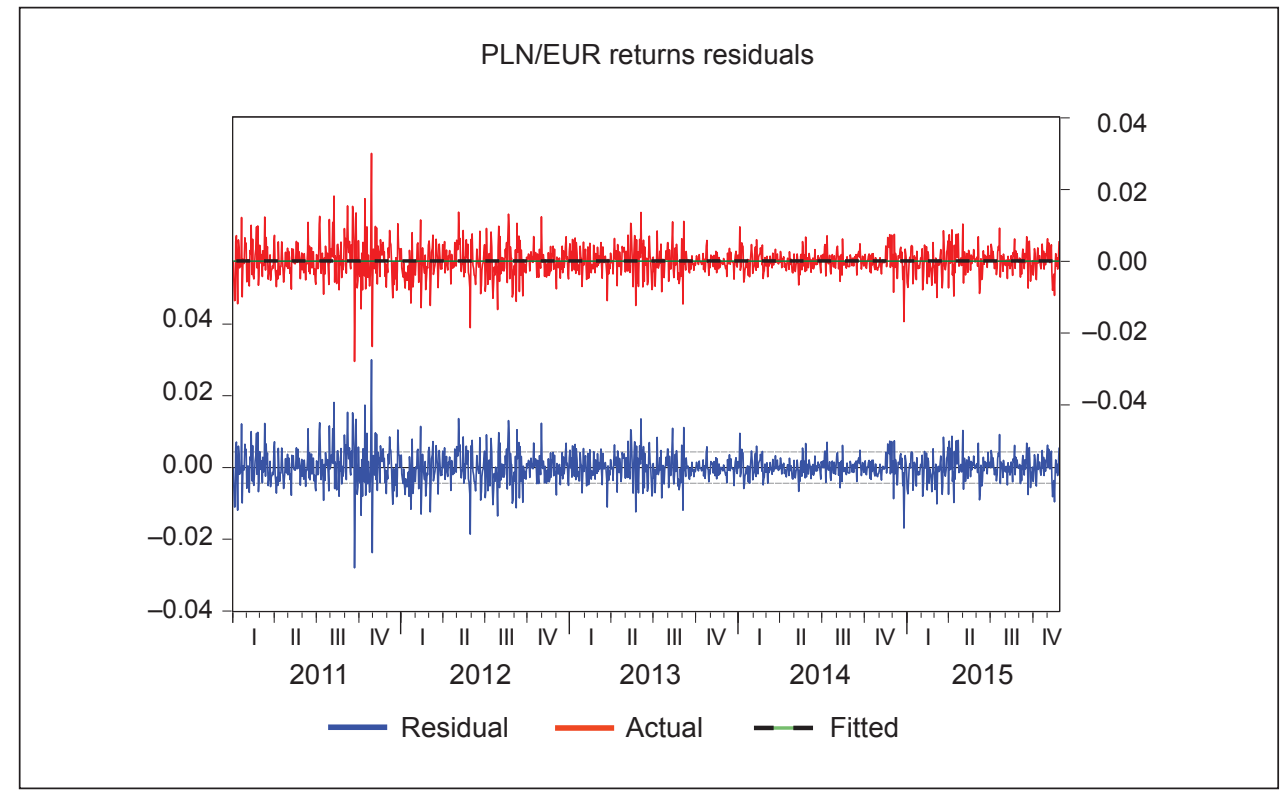

B: CZK/EUR Returns - Level of Conditional Volatility Including the Exchange Rate Intervention Announcement Day

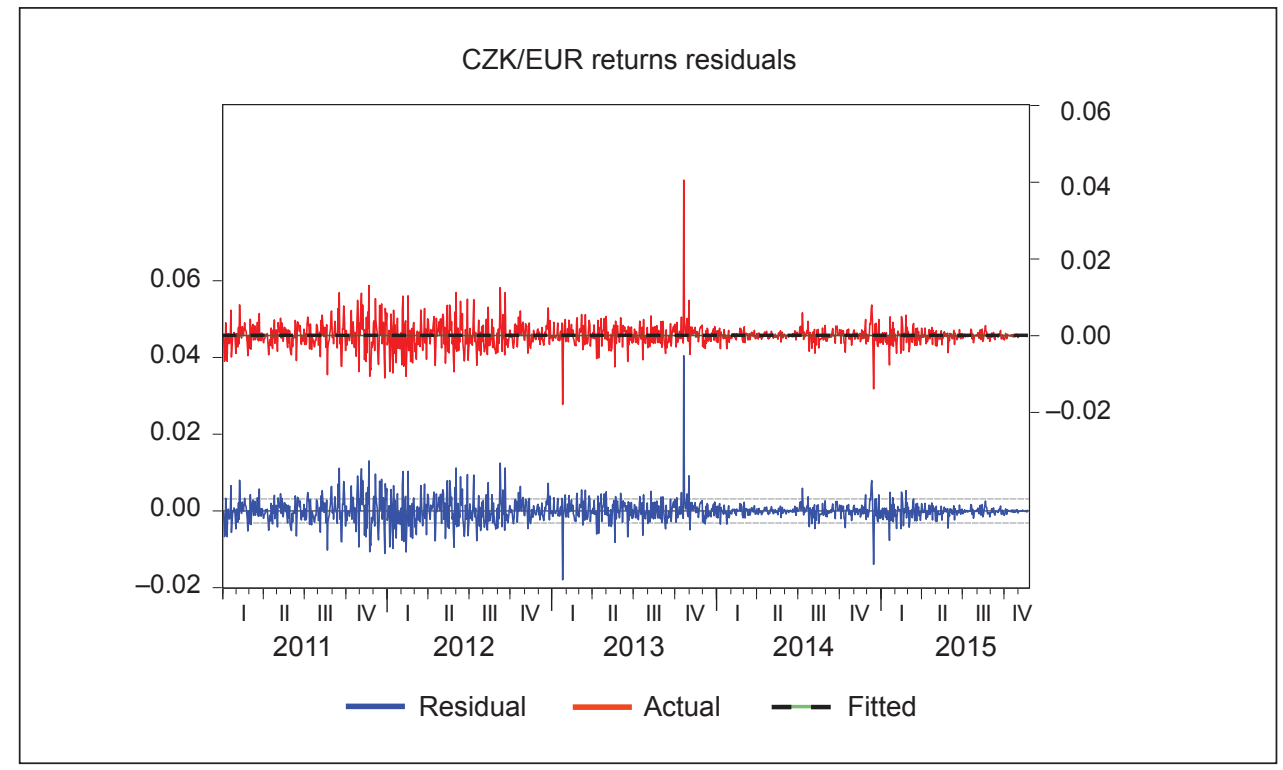




\section{C: CZK/EUR Returns - Level of Conditional Volatility Excluding 7 November 2013 (the day}

of exchange rate intervention announcement)

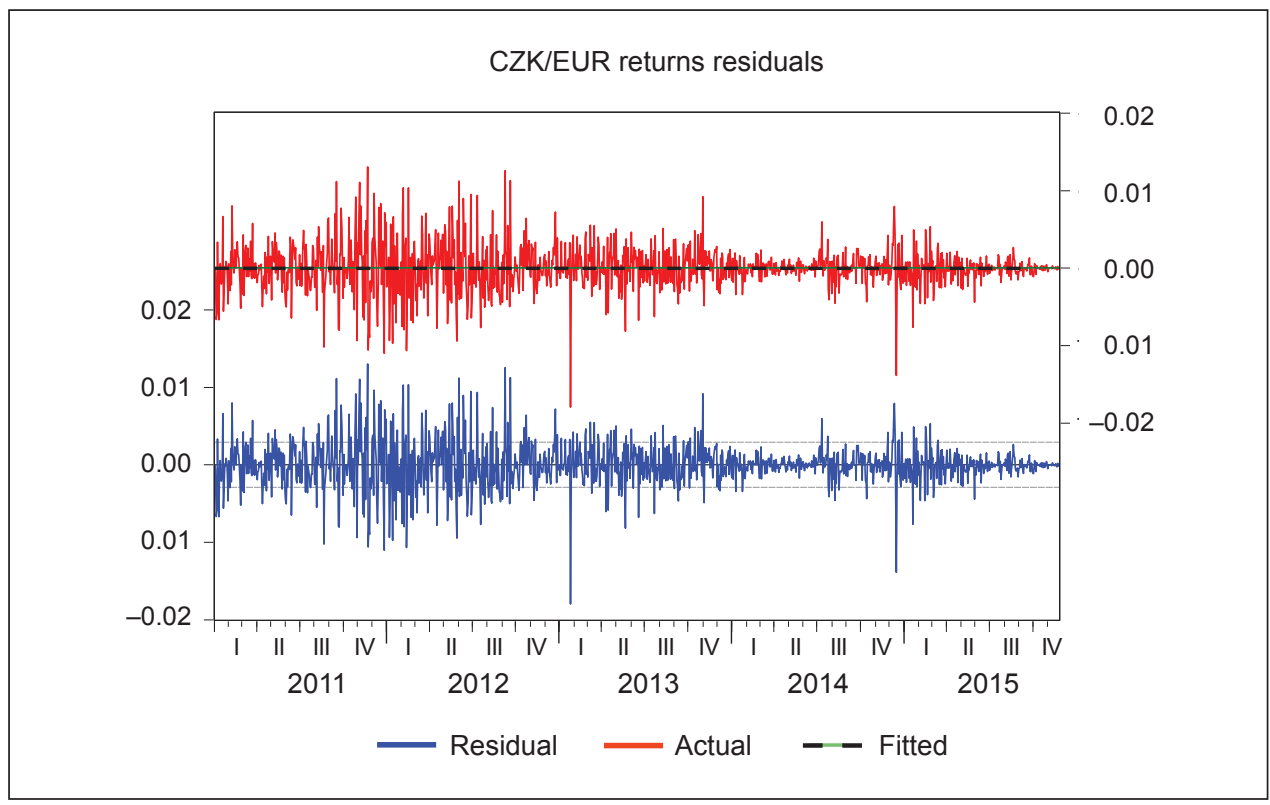

\section{D: HUF/EUR Returns - Level of Conditional Volatility}

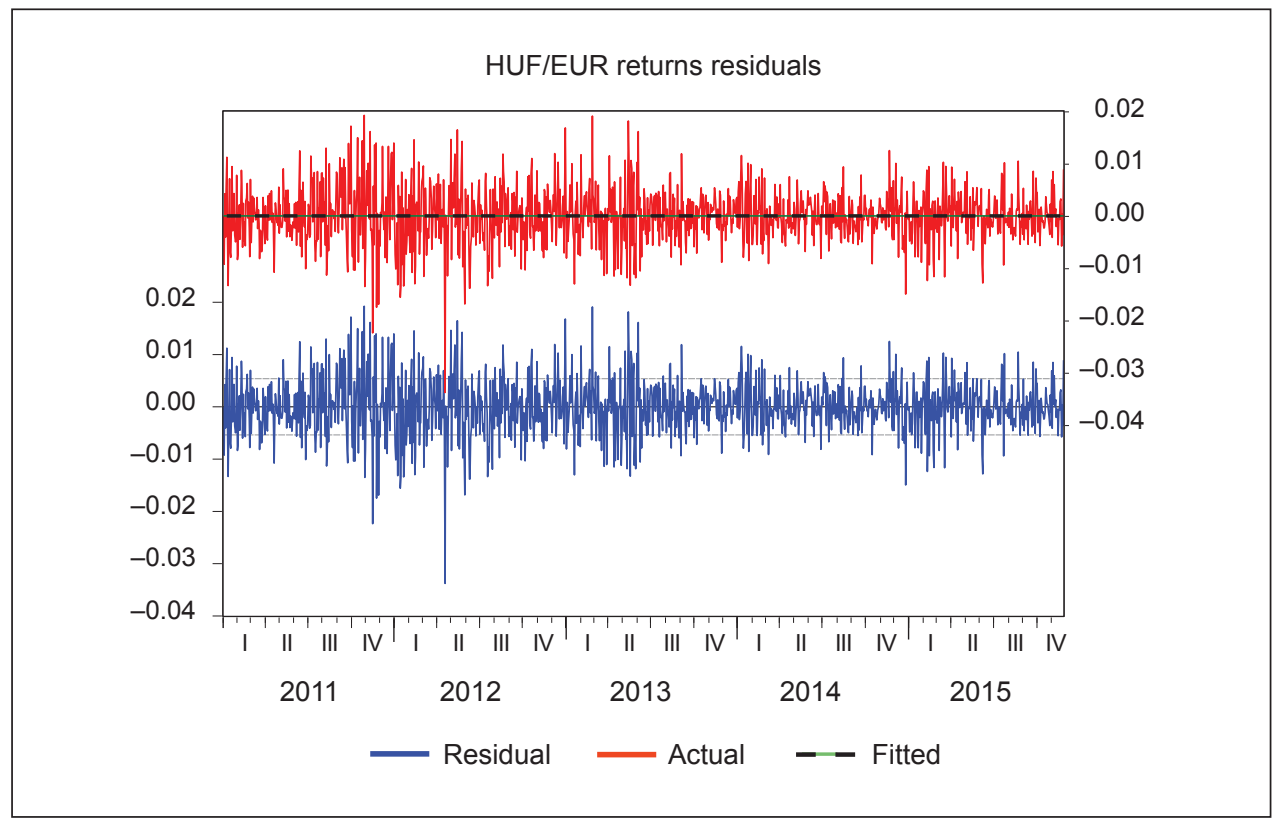

Source: Author - based on data from Metaquotes company 
Descriptive statistics for the continuously compounded returns of CZK/EUR, HUF/EUR, and PLN/EUR are presented in Table 1. The sample contains 1,603 observations for each currency pair. The highest standard deviation of exchange rate returns produces the Hungarian forint (0.54\%). ${ }^{1}$ The Czech market demonstrates the lowest standard deviation $(0.35 \%)$ among the examined markets. Following the $p$-value of Jarque-Bera test, the null hypothesis that data is normally distributed can be rejected. In a normally distributed series, skewness is 0 and kurtosis is 3. Likewise, values of the skewness and excess kurtosis for all three exchange rates indicate that the time series do not correspond to a normal distribution. On the top of that, the largest kurtosis is present in CZK/EUR returns due to the act of launching interventions. Neglecting the day of the intervention's announcement, the kurtosis and skewness decreased. In summary, the central bank's interventions changed the attributes of the exchange rate returns. Firstly, it shifted the skewness from negative to positive values and enlarged kurtosis. Secondly, the missing ARCH effect in the residuals suggests there is no volatility clustering or persistence after CNB took control over one side of the CZK/EUR exchange rate.

The examined exchange rates' conditional volatility is shown in Figures 2 A-D. For testing heteroskedasticity in the residuals, the Lagrange Multiplier (LM) test for autoregressive conditional heteroscedasticity $(\mathrm{ARCH})$ was implemented. PLN/EUR and HUF/EUR exhibit patterns of volatility persistence and clustering in Table 1. Regarding $\mathrm{CZK} / \mathrm{EUR}$ residuals, the results suggest there is no $\mathrm{ARCH}$ effect at the $5 \%$ and $1 \%$ level of statistical significance. Consequently, the $\mathrm{CZK} / \mathrm{EUR}$ returns without the day of intervention are tested and residuals show the presence of the ARCH effect, which allows using the class of (GARCH) models.

\subsection{Macroeconomic news}

The scheduled German macroeconomic news announcements were obtained from Reuters. The examined dataset contains announcements on:

(i) business climate (Market's Purchasing Managers' Index (PMI) from the Manufacturing and Non-Manufacturing Sectors, the German Business Climate Index (IFO), and the German ZEW Economic Sentiment Index),

(ii) the real economy (Industrial Production, GDP, Factory Orders, Change in the Number of Unemployed People),

(iii) prices (measured by CPI).

Altogether 9 German macroeconomic indicators are exa-mined. ${ }^{2}$

1 The biggest volatility of HUF/EUR from all 3 examined exchange rates is also evident from Figure 1.

2 PMI Index from the Manufacturing and Non-Manufacturing Sectors is a leading economic indicator - businesses react quickly to market conditions, and their purchasing managers hold perhaps the most relevant insight into the company's view of the economy. Purchasing managers rate the relative level of business conditions including employment, production, new orders, prices, supplier deliveries, inventories.

ZEW Economic Sentiment Index represents survey of about 275 German institutional investors and analysts who rate the relative 6-month economic outlook for Germany. 
All announcements are made monthly except for GDP, which is measured quarterly. Reuters provides investors with a macro-calendar that contains a clearly defined date and timing of news releases. Furthermore, the macro-calendar specifies the previous, expected, and actual value of the indicator. ${ }^{3}$ This paper follows Egert and Kočenda (2014) and examines the impact of news announcements on the exchange rates as the deviation of the news' actual value from the previously expected value. It is reasonable to hypothesize that a deviation or excess impact may then affect exchange rates. Formally, the excess impact news variable, or "surprise" as Andersen et al. (2007) call it, is labelled $y n_{i t}$ and defined as:

$$
y n_{i t}=\frac{\left(a n_{i t}-E_{t-1}\left[a n_{i t}\right]\right)}{\sigma_{i}},
$$

where $a n_{i t}$ stands for the value of a scheduled announcement $i$ at time $t ; i$ ranges from 1 to 9; $E_{t-1}\left[a n_{i t}\right]$ is the value of the announcement for time $t$ expected by the market at time $t-1$; $y n_{i t}$ is the excess impact news variable or surprise effect. ${ }^{4}$ As news is reported in different units they are standardized to empower for comparison. $\sigma_{i}$ is the sample standard deviation of the surprise component $\left(a n_{i t}-E_{t-1}\left[a n_{i t}\right]\right)$. The standardization does not affect the properties of the coefficients' estimates as the sample standard deviation $\sigma_{i}$ is constant for any announcement $i$. Hence, the macroeconomic variables enter into the model with a value of $y n_{i t}$ (non-zero) on an announcement day and a value of zero on non-announcement days.

\subsection{Central Bank Announcements}

The impact of the European Central Bank's meeting days is investigated using the date of the ECB meetings as a dummy variable. The variable takes the value of unity on days when the ECB meeting takes place, not distinguishing if the central bank took any rate decision or not.

German Business Climate Index (IFO) consists of survey of about 7,000 businesses which rate the relative level of current business conditions and expectations for the next 6 months.

$C P I$ is the German preliminary price index measuring monthly percentage change in the price level. Preliminary inflation adjusted quarterly percentage change of GDP.

Change in the Number of Unemployed People during the previous month.

Factory Orders are percentage monthly change in total value of new orders placed with manufactures.

Industrial Production is calculated as monthly inflation adjusted percentage change.

Monthly percentage change in inflation-adjusted Retail Sales excluding automobiles and gas stations.

3 Market expectations are constructed using a survey of the world's best-rated institutional analysts and economists approximately one week before the information is released. This number represents the market consensus and its value is taken from Reuters terminal. It is not the news itself that matters but the difference between the actual and expected value.

4 Time $t-1$ means the time before the news announcement during which the estimations were collected. 


\section{Methodology}

The dependent variables are the daily percentage returns of the CZK/EUR, PLN/EUR, and HUF/EUR exchange rates computed according to Equation 1. The volatility of the exchange rates can be either higher or lower on the day of the macroeconomic news announcement than the average exchange rate volatility. Kim (1998) claims that the conditional volatility changes when market participants are caught by surprise and must adjust their positions, thus leading to market price adjustment. However, reduced volatility should be the result of reduced uncertainty due to reductions of speculative trading based on incorrect information.

The models for individual time series were chosen following these criteria:

(i) eliminating the $\mathrm{ARCH}$ effect from the residuals,

(ii) eliminating serial correlations in the residuals,

(iii) considering the best AIC and SIC criterion (Javed and Mantalos, 2013).

Examining the impact of German macroeconomic news announcements on the conditional volatility of the exchange rate, the following EGARCH $(1,1)$ model is used:

mean Equation:

$$
r_{t}=\mu+\varepsilon_{t},
$$

variance Equation:

$$
\ln \left(\sigma_{t}^{2}\right)=\gamma_{1}+\gamma_{2}\left(\frac{\left|\varepsilon_{t-1}\right|}{\left|\sigma_{t-1}\right|}-\sqrt{\frac{2}{\pi}}\right)+\gamma_{3} \frac{\varepsilon_{t-1}}{\sigma_{t-1}}+\gamma_{4} \ln \left(\sigma_{t-1}^{2}\right)+\theta_{i} \sum_{i=1}^{9} N E W S_{i t}+\rho_{1} E C B_{t},
$$

where $r_{t}$ tands for the log of daily change of examined exchange rate returns, the error term $\varepsilon_{t}$ in mean Equation 3 is assumed to have conditional variance $\sigma_{t}^{2}$ specified in Equation $4, \mu$ denotes average returns. The variance Equation 4 includes the constant $\gamma_{1}, \mathrm{ARCH}$ term $\varepsilon_{t-1}^{2}, \mathrm{GARCH}$ term $\sigma_{t-1}^{2}$. The symbol $N E W S_{i t}$ captures the news announcement effect and represents nine German macroeconomic news variables transformed into daily variables by assigning the value of zero for days without the particular news announcement and the magnitude of the news (Equation 2) for announcement days. Dummy variable $E C B_{t}$ captures the effect of European Central Bank meetings.

The key benefit of the EGARCH $(1,1)$ model is in capturing the asymmetry (leverage) effect. This model captures asymmetric responses of the time-varying variance to shocks and ensures that the variance is always positive. This model is asymmetric due to the $\frac{\varepsilon_{t-1}}{\sigma_{t-1}}$ component in variance Equation 4. If the coefficient is negative, positive shocks generate less volatility than negative return shocks, assuming other factors remain unchanged. The magnitude of the shock is represented by the ARCH term $\left(\frac{\left|\varepsilon_{t-1}\right|}{\left|\sigma_{t-1}\right|}-\sqrt{\frac{2}{\pi}}\right)$, and the significance of the conditional variance is represented by the GARCH term $\left(\sigma_{t-1}^{2}\right)$.

Note that GARCH models with higher lags were also estimated, but they were not able to eliminate serial correlation from the residuals. Also threshold autoregressive conditional 
heteroscedasticity (TARCH) models with different lags were applied, but they failed to improve on the results obtained from the EGARCH models.

\subsection{Testable Hypothesis}

Based on the researched topic and given the GARCH methodology outlined above, the following testable hypotheses are formulated.

Hypothesis 1: German macroeconomic news announcements influence the conditional volatility of new EU country exchange rates on the day of announcement.

Hypothesis 2: ECB meeting days influence the conditional volatility of new EU country exchange rates.

Hypothesis 3: New EU market currencies show an asymmetric effect in exchange rate returns, i.e., downward price movements are associated with higher volatility whereas upward movements are associated with lower volatility.

Hypothesis 4: New EU market currencies present evidence of volatility clustering and persistence, which indicates that large and small log-returns tend to occur in clusters in financial time series.

Hypothesis 5: The Czech National Bank's currency interventions change the CZK/ EUR exchange rate characteristics.

\section{Empirical Results}

This paper reports the results of German macroeconomic news and ECB meeting days firstly on PLN/EUR exchange rate conditional volatility. Secondly, HUF/EUR and thirdly, $\mathrm{CZK} / \mathrm{EUR}$ are analysed. ${ }^{5}$

\subsection{PLN/EUR}

The best model from the GARCH family is selected according to the rules mentioned in Section 4 Methodology. The results of the EGARCH $(1,1)$ model with 1 asymmetry term and normal error distribution in Table 2 imply that the constant, ARCH, GARCH, and ASSYMETRIC terms are significant at the 1 per cent level. This means that the model is well specified. The significance of the ARCH and GARCH terms provides evidence of volatility clustering and persistence. It allows not rejecting Hypothesis 4. Despite the fact that the asymmetric term is significant, it has a positive sign, which leads to a rejection of Hypothesis 3 .

With reference to the examined variables, the IFO index and Factory Orders increase the conditional volatility on the day of the announcement. More specifically, one standard deviation in unanticipated change in Factory Orders increases the conditional volatility of PLN/EUR by $11.90 \%$. One may be surprised that one standard deviation in unanticipated change in the IFO index increases conditional volatility by $55.46 \%{ }^{6}$

5 The estimations were conducted using the Student version of EVIEWS software with the default settings.

6 The average daily return is $0.0021 \%$, so a rise of $55.46 \%$ would lead to a return of $0.0033 \%$. 


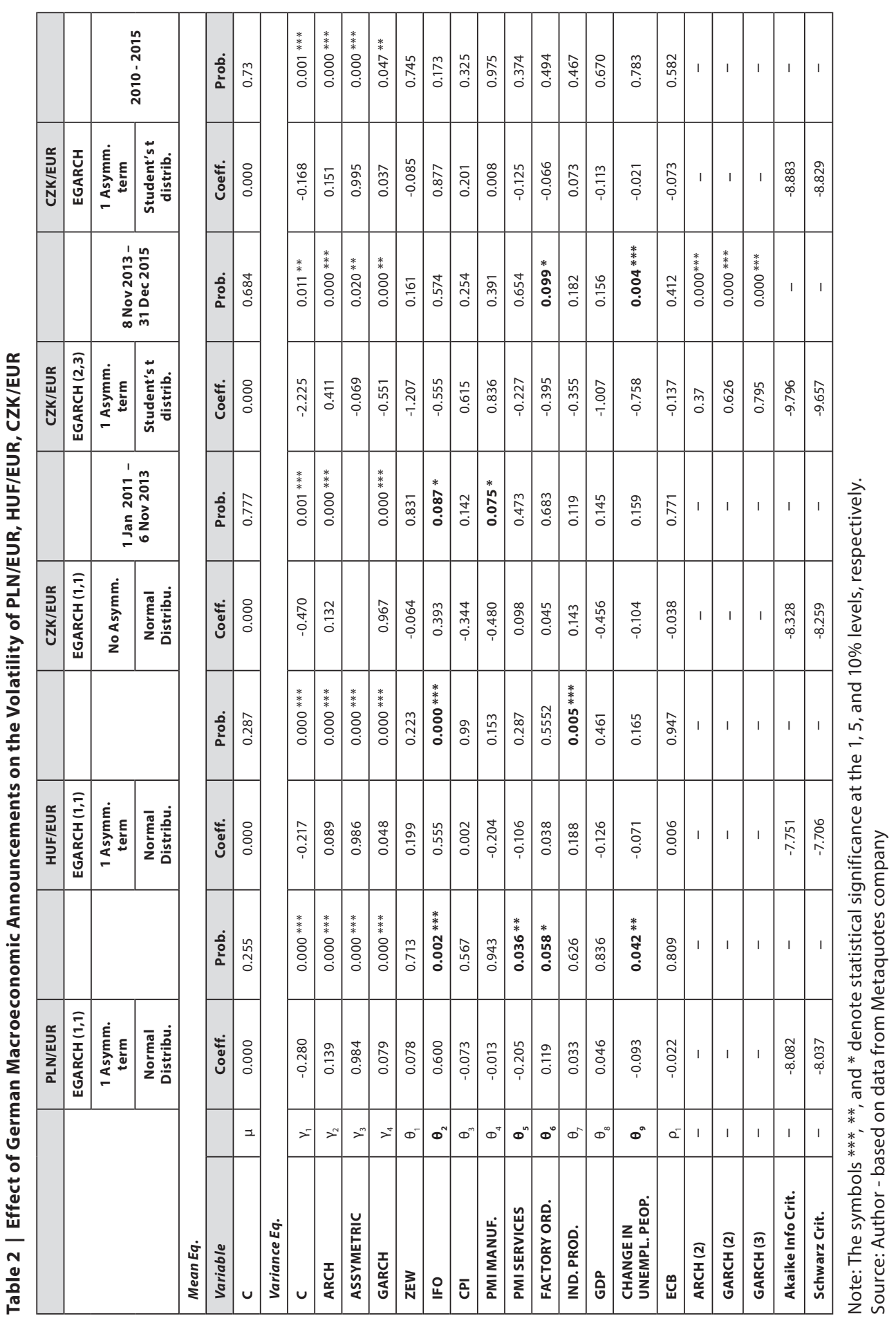


On the other hand, the one standard deviation in the PMI index from Service Sector and labour market data decrease PLN/EUR conditional volatility by $20.51 \%$ and $9.32 \%$, respectively. Said differently, this news has a calming effect on the Polish exchange rate. According to Fišer and Horváth (2010), the calming effect of news on the financial market may reflect that there is in general higher uncertainty in emerging markets and news is likely to diminish this uncertainty and calm down market participants. Following the above results, Hypothesis 1 is not rejected. Hence, it can be said that 4 German macroeconomic news (Factory Orders, the IFO index, the PMI index from Service Sector, and Labour market data) influence the conditional volatility of PLN/EUR on the day of announcement. On the other hand, Hypothesis 2 is rejected. ECB meeting days have no significant impact on the volatility of Polish exchange rate market.

\subsection{HUF/EUR}

Referring to the Hungarian exchange rate market, the same econometrical model as for PLN/EUR is applied. Examining the results, all the model parameters are significant. With respect to the positive sign of the asymmetric term, Hypothesis 3 may be rejected. Significance of ARCH and GARCH term in the equation leads to not rejecting Hypothesis 4 . $^{7}$

When it comes to macroeconomic variables, Hypothesis 1 is not rejected. Industrial Production and the IFO index increase HUF/EUR conditional exchange rate volatility on the day of announcement. One standard deviation in unanticipated change in the IFO index increases the conditional volatility of HUF/EUR by $55.46 \%$. Notably, the impact of the IFO index on the HUF/EUR exchange rate conditional volatility is very similar to PLN/EUR. Considering the number of significant macroeconomic news variables for conditional exchange rate volatility, German macroeconomic news plays a more important role in the Polish than in the Hungarian exchange rate market. The insignificance of ECB meeting days allows rejecting Hypothesis 2.

\subsection{CZK/EUR}

This paper first reports the results for the period before the Czech National Bank (CNB) launched currency interventions (1 January 2010 - 6 November 2013). Second, the period after introducing currency interventions is examined ( 8 November $2013-31$ December 2015). Third, these two periods are put together and examined without the day of the intervention announcement.

\subsubsection{CZK/EUR before currency interventions ( $1^{\text {st }}$ January 2010 - 6 November 2013)}

The time period before the introduction of currency interventions is characterized by higher exchange rate volatility compared to the time period after the CNB started to prevent the Czech koruna from appreciating below 27 korunas for 1 euro. ${ }^{8}$

$7 \quad$ Please, see the results in Table 2.

8 Please see Figure 2 B. 
The same process as before is applied and the best model for estimating the impact of German macroeconomic data on CZK/EUR conditional volatility is set. The EGARCH $(1,1)$ model with no asymmetry parameter is selected. ${ }^{9}$ Results of model specification in Table 2 reveal no presence of leverage effect, so Hypothesis 3 may be rejected. Furthermore, the significance of the ARCH and GARCH terms in the model support not rejecting of Hypothesis 4.

As for macroeconomic news announcements, the IFO index increases CZK/EUR conditional volatility and the PMI index from Manufacturing Sector decreases volatility. Peculiarly, one standard deviation in unanticipated change in the IFO index increases the conditional volatility of CZK/EUR by $39.26 \%$. One could see the same impact of the IFO index on the PLN/EUR and HUF/EUR exchange rates. Moreover, one standard deviation in unanticipated change in the PMI index from Manufacturing Sector decreases the conditional volatility of CZK/EUR by $47.99 \%$.

\subsubsection{CZK/EUR Currency Intervention Period (8 November 2013- 31 December 2015)}

The period of currency interventions is analysed separately in order to investigate if the decision of the CNB to start intervening on the foreign exchange market changed the characteristics of the Czech currency market and its reaction to German macroeconomic news announcements. The CZK depreciated against the euro by $4.7 \%$ on 7 November 2013 , which is recognizable from Figure $2 \mathrm{~B}$.

As for a macroeconomic model, EGARCH $(2,3)$ model with 1 asymmetry term and Student's t-error distribution is chosen. ${ }^{10}$ The significance of both ARCH and three GARCH terms enables to not reject Hypothesis 4. The asymmetry component is significant with a negative sign, which leads to not rejecting Hypothesis 3 , saying that negative news causes higher variance than positive news.

Regarding macroeconomic variables, the announcement of labour market data has a calming effect on the CZK/EUR conditional volatility. The same impact can be seen in the Polish exchange rate market. The EGARCH $(2,3)$ model with 1 asymmetry term showed the best results in terms of parameter estimation. However, neither EGARCH $(2,3)$ nor any of the TGARCH or GARCH models with normal, Student's $t$, or GED distributions of different lags were able to eliminate serial correlation in the residuals. The economical explanation may lay behind the central bank's monetary policy. Keeping the CZK/EUR exchange rate close to 27 results in exchange rate stagnation and daily returns stick very close to zero. These empirical results support to not rejecting Hypothesis 5 .

$9 \quad$ A simple GARCH model with different lags was not able to eliminate serial correlation from residuals. The asymmetry term in the variance equation was not significant and excluding it did not worsen the model parameters.

10 Hsieh (1989) shows that GARCH models with a standardized $t$ distribution for the residuals are useful for modelling the time-varying nature of daily exchange rate returns. 


\subsubsection{CZK/EUR 2010-2015}

The EGARCH $(1,1)$ model with 1 asymmetry term and Student's $t$-distribution was employed. All the parameters of the model are significant. Therefore, Hypothesis 4 is not rejected. A significant positive asymmetry component results in rejecting Hypothesis 3 . Regarding macroeconomic variables, no German macroeconomic data affect the conditional variance of CZK/EUR volatility. This may be explained by different patterns of CZK/EUR volatility before and after currency interventions. Putting together different characteristics of the CZK/EUR exchange rate may result in no significance of German macroeconomic data. Consequently, Hypothesis 1 is rejected. As for ECB meeting days, they are insignificant, too. Hypothesis 2 can be rejected. All the results are presented in Table 2 and are in line with Egert and Kočenda (2014), who showed that the effects of news announcements on the financial markets of new EU countries change over time and differ with the specific type of macroeconomic news. Similar results are in Galati and Ho (2003) and Ehrmann and Fratzscher (2007).

\section{Conclusion}

Paper studies the effect of German macroeconomic news and European Central Bank meeting days on the conditional variance CZK/EUR, PLN/EUR, HUF/EUR. Empirical results provide evidence that German macroeconomic data announcements influence the conditional volatility of the new EU exchange rates: (i) The IFO index and Factory Orders increase the conditional volatility of PLN/CZK. On the other hand, the PMI index from Service Sector and data from the labour market decrease the conditional volatility of the PLN/EUR exchange rate. (ii) When it comes to the Hungarian foreign exchange market, the IFO index and Industrial Production increase the conditional volatility of HUF/EUR. (iii) Regarding the Czech market, the IFO index increases and the PMI index from Manufacturing Sector decreases CZK/EUR conditional variance on the day announcement before the Czech National Bank launched currency interventions. CNB currency interventions changed CZK/EUR returns' attributes. Furthermore, currency interventions have downgraded the impact of German macroeconomic data on the Czech currency market. Finally, the empirical results show that there is no leverage effect in the all examined financial time series.

The above results of three new EU currencies are consistent with Kočenda and Moravcová (2016) who find, that the longest reaction in terms of significant abnormal returns after the German/Eurozone news release can be traced to the announcements of the PMI indices, Retail Sales, the IFO and Industrial Production. The data show that ECB meeting days do not influence new EU exchange rate volatility during 2010-2015.

Identifying the impact of German macroeconomic news announcements on new EU currency markets may improve the forecasting techniques of policy makers. The exchange rate is an important part of international trade and therefore forecasting is relevant for policymakers and local central banks. Understanding the relationship between German macroeconomic data and new EU currency markets can be beneficial for diversification and 
hedging strategies. International investors may benefit from diversification by allocating part of their portfolios to new EU market assets. According to Jotikasthira et al. (2012), mutual and hedge fund holdings domiciled in developed countries account for about 13-19\% of the free-float adjusted market capitalization in new EU countries $(16.6 \%$ in the Czech, $17 \%$ in the Hungarian, and $13.3 \%$ in the Polish equity markets).

\section{References}

Andersen, T. G., Bollerslev, T., Diebold, F. X., Vega, C. (2003). Micro Effects of Macro Announcements: Real-Time Price Discovery in Foreign Exchange. American Economic Review, 93(1), 38-62, https://doi.org/10.1257/000282803321455151

Andersen, T. G., Bollerslev, T., Diebold, F. X., Vega, C. (2007). Real-Time Price Discovery in Global Stock, Bond and Foreign Exchange Markets. Journal of International Economics, 73(2), 251-277, https://doi.org/10.1016/j.jinteco.2007.02.004

Bollerslev, T. (1986). Generalized Autoregressive Conditional Heteroskedasticity. Journal of Econometrics, 31(3), 307-327, https://doi.org/10.1016/0304-4076(86)90063-1

Büttner, D., Hayo, B. (2012). EMU-Related News and Financial Markets in the Czech Republic, Hungary and Poland. Applied Economics, 44(31), 4037-4053. http://dx.doi.org/10.1080/00 036846.2011.587775

Büttner, D., Hayo, B., Neuenkirch, M. (2012). The Impact of Foreign Macroeconomic News on Financial Markets in the Czech Republic, Hungary, and Poland. Empirica, 39(1), 19-44, https://doi.org/10.1007/s10663-010-9153-0

Cavusoglu, N. (2011). Exchange Rates and the Effectiveness of Actual and Oral Interventions: A Survey on Findings, Issues and Policy Implications. Global Economy Journal, 10(4), 1-40, https://doi.org/10.2202/1524-5861.1694

Diebold, F. X., Yilmaz, K. (2009). Measuring Financial Asset Return and Volatility Spillovers with Application to Global Equity Markets. Economic Journal, 119(534), 158-171, https://doi. org/10.1111/j.1468-0297.2008.02208.x

Égert, B., Kočenda, E. (2014). The Impact of Macro News and Central Bank Communication on Emerging European Forex Markets. Economic Systems, 38(1), 73-88, http://dx.doi.org/10.1016/j.ecosys.2013.01.004

Ehrmann, M., Fratzscher, M. (2007). Communication by Central Bank Committee Members: Different Strategies, Same Effectiveness? Journal of Money, Credit and Banking, 39(2-3), 509-541, https://doi.org/10.1111/j.0022-2879.2007.00034.x

Erenburg, G., Kurov, A., Lasser, D. J. (2006). Trading Around Macroeconomic Announcements: Are All Traders Created Equal? Journal of Financial Intermediation, 15(4), 470-493, http://dx.doi.org/10.1016/j.jfi.2005.07.003

Evans, M. D. D., Lyons, R. K. (2008). How Is Macro News Transmitted to Exchange Rates? Journal of Financial Economics, 88(1), 26-50, http://dx.doi.org/10.1016/j.jfineco.2007.06.001

Fišer, R., Horváth, R. (2010). Central Bank Communication and Exchange Rate Volatility: A GARCH Analysis. Macroeconomics and Finance in Emerging Market Economies, 3(1), 25-31, http://dx.doi.org/10.1080/17520840903498099

Fratzscher, M. (2006). On the Long-Term Effectiveness of Exchange Rate Communication and Interventions. Journal of International Money and Finance, 25(1), 146-167, http://dx.doi. org/10.1016/j.jimonfin.2005.10.007 
Galati, G., Ho, C. (2003). Macroeconomic News and the Euro/Dollar Exchange Rate, Economic Notes, 32(3), 371-398, https://doi.org/10.1111/1468-0300.00118

Hanousek, J., Kočenda, E., Kutan, A. (2009). The Reaction of Asset Prices to Macroeconomic Announcements in New EU Markets: Evidence from Intraday Data. Journal of Financial Stability, 5(2), 199-219, http://dx.doi.org/10.1016/j.jfs.2008.01.003

Hanousek, J., Kočenda, E. (2011). Foreign News and Spillovers in Emerging European Stock Markets. Review of International Economics, 19(1), 170-188.

Hayo, B., Kutan, A. M., Neuenkirch, M. (2010). The Impact of U.S. Central Bank Communication on European and Pacific Equity Markets. Economics Letters, 108(2), 172-174, http://dx.doi.org/10.1016/j.econlet.2010.05.006

Hsieh, D. (1989). Modeling Heteroscedasticity in Daily Foreign-Exchange Rates. Journal of Business and Economic Statistics, 7(3), 307-317, https://doi.org/10.1080/07350015.1989.10509740

Jansen, D.-J., De Haan, J. (2005). Talking Heads: The Effects of ECB Statements on the EuroDollar Exchange Rate. Journal of International Money and Finance, 24(2), 343-361, http://dx.doi.org/10.1016/j.jimonfin.2004.12.009

Javed, F., Mantalos, P. (2013). GARCH-Type Models and the Performance of Information Criteria. Communications in Statistics: Simulation and Computation, 42(8), 1917-1933.

Jones, B., Chieng-Ting, L., Masih, M. M. (2005). Macroeconomic Announcements, Volatility, and Interrelationships: An Examination of the UK Interest Rate and Equity Markets. International Review of Financial Analysis, 14(3), 356-375, http://dx.doi.org/10.1016/j.irfa.2004.10.001

Jotikasthira, Ch., Lundblad, Ch., Ramadorai, T. (2012). Asset Fire Sales and Purchases and the International Transmission of Funding Shocks. Journal of Finance, 67(6), 2015-2050, https://doi.org/10.1111/j.1540-6261.2012.01780.x

Kim, S. J. (1998). Do Australian and the US Macroeconomic News Announcements Affect the USD/AUD Exchange Rate? Some Evidence from E-GARCH Estimations. Journal of Multinational Financial Management, 8(2-3), 233-248, http://dx.doi.org/10.1016/ S1042-444X(98)00029-2

Kočenda, E., Moravcová, M. (2016). Intraday Effect of News on Emerging European Forex Markets: An Event Study Analysis. IES. WP 20/2016.

Longmore, R., Robinson, W. (2005). Modelling and Forecasting Exchange Rate Dynamics: An Application of Asymmetric Volatility Models. Money Affairs, 18(1), 23-56.

$\mathrm{Ng}$, A. (2000). Volatility Spillover Effects from Japan and US to the Pacific-Basin. Journal of International Money and Finance, 19(2), 207-233, http://dx.doi.org/10.1016/ S0261-5606(00)00006-1

Poplawski, K. (2016). The Role of Central Europe in the German Economy the Political Consequences. Centre for Eastern Studies, September/2016. ISBN 978-83-62936-84-7.

Rigobon, R., Sack, B. (2008). Noisy Macroeconomic Announcements, Monetary Policy, and Asset Prices, in Campbell, J. Y., ed., Asset Prices and Monetary Policy. The University of Chicago Press, Chicago, 335-370.

Škubna, O., Smutka, L., Steininger, M., Maitah, M. (2011). Selected Central European Countries' Foreign Trade Development. Ekonomická Revue-Central European Review of Economic Issues, 14(1), 21-35, https://doi.org/10.7327/cerei.2011.03.02

Taylor, S. J. (1986). Forecasting the Volatility of Currency Exchange Rates. International Journal of Forecasting, 3(1), 159-170, https://doi.org/10.1016/0169-2070(87)90085-9

Yoon, S., Lee, K. S. (2008). The Volatility and Asymmetry of Won/Dollar Exchange Rate. Journal of Social Sciences, 4(1), 7-9, https://doi.org/10.3844/jssp.2008.7.9 